ence on the nature of any organization set up for civil research. Where the Broadsheet comes close to the heart of the problem is in its recognition that the National Economic Development Council must play a vital part in coordinating the national economic plan with which must be integrated the greatly extended and systematized programme of civil development contracts and 'earmarked' grants, which it desiderates, and in its suggestion that the same council should be equipped for the purpose with a technical-economic arm.

This guidance of scientific effort is recognized as an integral part of the development of an effective national plan for economic growth, and the Broadsheet rightly recognizes that this will call for expenditure on a scale greater than the Treasury has ever envisaged for promoting civil defence. This is particularly true of information services, and here the Broadsheet lays the responsibility for initiative firmly on the Government side. Although in the long term the expansion of technical education will be the determining factor, in the short term only Government initiative will suffice to improve significantly the dissemination of relevant technical information to the scientifically backward firms-which still comprise a large section of British industry.

The Broadsheet looks favourably on the possibility of some considerable extension of the compulsory levy for research associations, perhaps jointly with a levy for industrial training, but it clearly recognizes that the present efforts of the Department of Scientific and Industrial Research in the information field are on nothing like the scale that is required. Whether the Department can fairly be expected to expand that effort on the necessary scale is a matter for discussion. It is part of the larger problem of information and intelligence services generally, and while the Department persists in its policy of silence as to the activities of its Intelligence Division, any proposal to extend its responsibilities could well fail to command wide support.

What is perhaps most significant in the Broadsheet is this recognition that intelligence services have a vital part to play in the effective deployment of Britain's scientific and technological effort, and that the financial and other resources for such work must be found if there is not to be waste and overlap. That is a major point to be considered in planning the organization of Britain's effort in civil research. It should not be overlooked, however, that at present an essential part of library and information services of Britain - the public library services - are the responsibility of the Minister of Education, while the university libraries depend, through the Univer. sity Grants Committee, on the Treasury and the colleges of technology on local education authorities or the Ministry of Education. The Broadsheet gives no lead as to the answers to these and other questions. Its examination of the research associations is likewise searching and inconclusive, but, like the debate in the House of Commons and the report from the Federation of British industries, it asks many of the questions on which the Trend and the Robbins Committoes have already reported. Decisions on such questions may be the easier for lively and informed discussion beforehand-discussion which should be at pains to ensure that no vital or important factors are overlooked or not considered when at last the decisions are taken.

\title{
RESEARCH IN EDUCATION
}

$\mathrm{T}$ HE annual report of the Nuffield Foundation for $1962-63^{*}$ is of particular interest for its emphasis on educational research. Almost $£ 370,000$ of some $£ 1.8$ million allocated during the year was for education, and while this includes $£ 120,000$ for a residential wing for New Hall, the recently established third women's college at Cambridge, and $£ 77,000$ for the new Shakespeare Centre at Stratford-upon-Avon, the remainder of this allocation is mainly for research. It is worthy of note in this connexion, moreover, in view of many public statements made during the year about the lack of financial support for scientific research in Britain, that the report pointedly states that there has been no increase in the number of applications received for grants by the Foundation in the various scientific fields with which it is concerned. Referring more specifically to complaints that insufficient help is available for particular research projects, the report reaffirms that the Foundation cannot act or play its activating part until it is brought into touch with able people whose promise commands its interest and support. Its recent experience indicates that there is no overwhelming evidence of large-scale neglect of worth-while projects and of people of ability who need financial help to carry out original research.

It is possible that such projects and such people may be unnoticed because some of those with good ideas are

* The Nuffield Foundation. Eighteenth Report, 1962-1963. Pp. xiil + 192. (London: The Nuffeld Foundation, 1963.) See also p. 526 of this issue of Nature. hesitant in putting them forward for consideration by others, and the Foundation would warmly welcome suggestions for removing any obstacles to communication. It prefers, in fact, at times to discuss projects before they have reached their final form, and recognizes that a grantgiving body may sometimes be able to give encouragement and advice in the early stages of developing an idea into a practical project. Nevertheless, it inclines to the view of the Advisory Council on Scientific Policy that it is the central responsibility of research workers themselves to develop promising programmes of research.

This comment on the lack of evidence that promising projects and people are to any serious extent unable to find financial support appears to be true of educational research in general, in spite of the small scale of such research in Great Britain at present. The Minister of Education, Sir Edward Boyle, expressed the opinion in the House of Commons on July 24 that the difficulty lay rather in finding teams really capable of doing justice to the projects, and the proposals for establishing an Educational Research Council made to Sir Edward were partly stimulated by the need to train more research workers in this field. Meanwhile, the Nuffield Foundation's own contribution to educational research is proportionate to that of the Ministry of Education itself which, according to Sir Edward, is not expected to exceed $£ 250,000$ on completion of all the projects now in hand.

Sir Edward had more particularly in mind projects concerned with the schools curricula and examinations, 
and the Nuffield Foundation sees its own present programmo for assisting the revision of school science curricula and the production of the range of teaching resourens that the new aims and mothods will require as expressing another of its roles - that of entrepreneur. The factfinding enquiries, for which Sir Eric Ashby called in his presidential address to the British Association at Abordeen (see Nature, 199, 835, 877; 1963), would seem to call for the exercise of yet a third function which has characterized the activities of the Foundation-enquiries aimed at social fact-finding and including the application of mathomatical techniques to social probloms. The Statistical Research Unit in Sociology at the University of Koole, for which the report notes an ondowment grant, could well make important contributions in this field.

Moanwhile, tho Nuffield Foundation has recognized that the widespread desire for the roform of school science toaching is well founded and important, and has brought togethor, in larger and more powerful toams than would otherwise have been possible, men and womon, mostly school toachors of outstanding ability, who have the enthusiasm and ability to carry out the work. The projocts for improving biology, chemistry and physics curriculn for eleven- to sixten-year-olds are well under way, and it is hoped that some of the preliminary material will bo tried out in selected schools during the year that started in Soptember 1963. Many schools have been extremely generous and helpful in seconding teachers to work full-time on the projects, and the Foundation fully recognizes the value of this co-operation from schools and education authorities, despite the great difficulties which such secondments have often caused them. The vigour and promise of these schemes dorive largely from the genoral desire for such work to be done, and tho report describes the result as one of the most exciting fields of action with which the Foundation has had the good fortune to be coneerned.

One of two independent schemos which the Foundation is also supporting is that for improving the teaching of biology in schools, technical colloges and universities. A Joint Committee of the Royal Society and the Institute of Biology, of which Prof. W. O. Jimes is chairman, is at present particularly concorned with the rolation of sixthform courses to university requirements, and, as a first step, in secking to collect information on the probable future requirements of university departments and the capabilities of sixth-form teaching to meet them. The Committee also hopes to make recommendations on the degree to which standardization is desirable and to survey present biology courses in universities. An investigation along these lines is clearly of the type which Sir Eric Ashby himsolf had in mind and it would also be a valuable preliminary to any oxtension of the Foundation's biology project to sixth-form level. Accordingly, the Foundation has made a grant of $£ 12,000$ over two years. A guarantee of up to $£ 10,000$ over three years has also been made to tho Royal Institute of Chemistry's new venture in founding a Chemical Education Journal, in viow of its bearing on chemistry teaching at all levels.

The Foundation is also supporting several mathomaties teaching programmes, but a major developrnent of the year has been the increased support given to firther the teaching of modern languages. This involves a project for preparing a full range of teaching resources for an introductory courso in French for children between the ages of eight and thirteen. As in the science-tonching projects, the prepuration will be dono by practising teachers under the leadership of a full-time organizer with the help of a consultative committee, and the project includes pupils' tests, teachers' guides, wall-charts and othor andio-visual materials. It is linked with the Ministry of Education's pilot scheme in the teaching of French in primary schools to begin in September 1964 .

Apart from this, the Foundation mado several small individual grants to education committees and schools to assist them in producing or obtaining material to try out new methods of language teaching. It is also exploring with the training colloges, institutes of education and other bodies the possibilities for future development of now mothods of training teachers, and has made a grant to the University of Durham for a factual survey of teacher-trainer, including tho teaching staffs of all training colleges, and of all departments and institutes of education. In the same ficld comes the grant of $£ 10,500$ to the British Association for the Advancement of Science to assist the first three years of the Association's project for science lectures for staff and students of training colleges.

Only at a fow points do these activities of tho Nuffield Foundation touch the universitios or provide the factual enquirios into university needs and toaching methods which Sir Eric Ashby urged on the British Association. Their indirect effect could, however, be considerable, and they demonstrate that there is a more considerable effort in educational rosoarch in Britain than Sir Eric's addross suggests. A fuller picture is given in the appendixes to a report published last July on research into technical education. This report by a working party, of which Prof. A. V. Judges was chairman, and which was sot up as a result of a conforence at the University of London in July 1961, did not interpret its terms of reference too narrowly (see Nature, 199, 1240; 1963), and these appendixes provide a picture of educational research in progress affecting not simply the technical colleges or colleges of tochnology but also the university institutions.

This report once again insists on the noed for more research workers, and this alone should help to draw the universities into this field. The working party's report, moreover, by implication rather than specifically, indicates how large is the. fiold for educational research in the university field, including not merely the factual onquiries to which Sir Fric Ashby pointed, but also the room for experiment. This is all tho more urgent if Britain is to make the most effective use of what is the real limit to oxpansion in higher education - in the supply of trained teachors. The Nuffield Foundation would not claim that what it is doing is more than pioneering or exploring some of the new and exciting possibilitios. Its report manifestly points the way forward and, whethor or not a Council for Educational Rosoarch is appointed, the major share of activity in this field cannot be loft to a private Foundation. If not through a massive expansion of the National Foundation for Educational Research, as and whon the programmes can be formulated and competent investigators found, thon in other appropriate ways the Government must make available sufficient resources to mest the noed. Whatever else the Robbins Committee has recommendod, the expansion of higher oducation can only be undertaken on an officient and economic busis when educational research has providod the answers to such quostions as Sir Eric Ashby indicated and that offort should be a first priority. 